\title{
Knobbly knees and epilepsy: an interesting case linking the two?
}

\author{
Christopher Myles Rowe, Gilbert Thomas-Black
}

Intensive Care Unit, The Whittington Hospital, London, UK

\section{Correspondence to}

Dr Christopher Myles Rowe, christopher.m.rowe@doctors. net.uk

Accepted 15 October 2014

\section{DESCRIPTION}

A 43-year-old woman presented to the emergency department in a rural South African hospital with knee pain following a fall. Her medical history included epilepsy, for which she took phenytoin. Examination of the knee revealed joint swelling and tenderness; the range of motion was from $20^{\circ}$ to $90^{\circ}$ limited by pain, but there was no neurovascular compromise. Concomitantly, numerous firm subcutaneous nodules were noted. Lateral and anteroposterior radiographs of the knee (figures 1A, B, respectively) revealed multiple, small, calcified nodules longitudinally aligned with the muscle fibres of the posterior compartment of the thigh and calf. Full blood count, urea and electrolytes, calcium and liver function tests were unremarkable; however, cysticercosis serology was positive.

Cysticercosis is due to the tapeworm, Taenia solium. It is endemic in areas of poverty, strongly associated with poor food hygiene, being contracted through the faecal-oral route ${ }^{1} 2: T$. solium eggs are passed in human faeces, which can be consumed by pigs or directly by humans. ${ }^{1}$ Undercooked pork and/or faeces is consumed by humans: digestive enzymes remove the egg's protective capsule, creating oncospheres, which penetrate the gut wall and migrate via the vascular system to the skin, muscle, eyes and nervous system, where the oncospheres hatch to form cysticerci. ${ }^{1}{ }^{2}$ Migration to the nervous system is termed neurocysticercosis, effecting the brain parenchyma and/or extra-parenchymal structures (ventricles, cisterns, sub-arachnoid space, spinal cord or eyes). ${ }^{12}$

Full neurological examination revealed no focal deficits, with no evidence of ocular cysticercosis on external examination of the eye and funduscopy. The patient was referred to the regional hospital for a CT of the brain to exclude brain involvement and consideration of antihelminthic treatment; neurocysticercosis can be a (potentially reversible) cause of epilepsy. ${ }^{1}{ }^{2}$ Unfortunately, due to the patient failing to attend outpatient clinics, the results of the CT scan and subsequent treatments are not known.
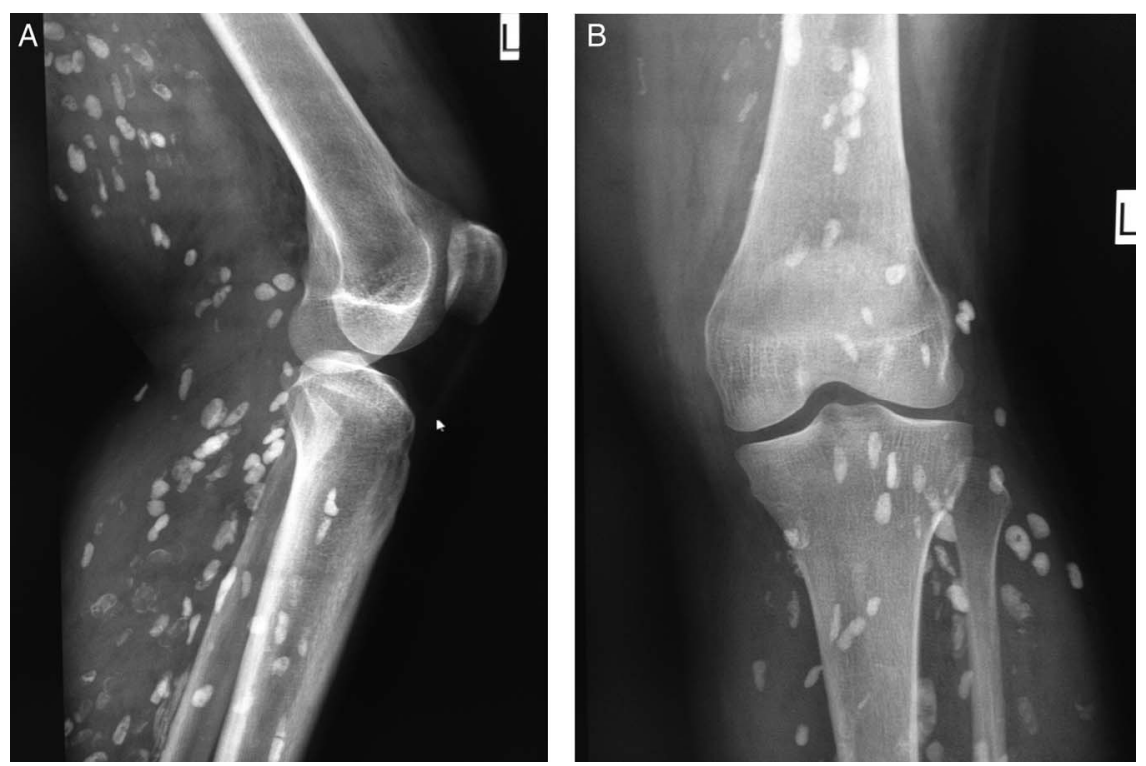

Figure 1 A lateral (A) and an anteoposterior (B) radiograph of a knee demonstrating numerous calcified granulomas within the musculature of the posterior thigh and calf. The lesions represent the final, non-viable stage of the cysticerci. 


\section{Learning points}

- Neurocysticercosis is the most common neural helminthic infection worldwide, potentially causing headaches, hydrocephalus, raised intracranial pressure, focal neurological deficits, and epilepsy and seizures ${ }^{12}$ - the latter symptom being the most common presentation, in up to $70 \%$ of cases. ${ }^{1}$

- Cysticerci exist in multiple stages: initially, as a viable (vesicular) stage, in which they can remain for years with minimal inflammatory response. ${ }^{1}$ Degeneration of the cysticerci, for example, by an immunological response, can induce the colloid stage, often associated with a strong inflammatory response and severe symptoms; ${ }^{12}$ beyond this stage, the cysticerci become non-viable and forms granules (granular stage) and eventually mineralise (calcified stage). ${ }^{12}$

- On CT of the brain, vesicular lesions are well-defined, non-enhancing, with no surrounding oedema (demonstrating a 'dot in a hole' appearance), ${ }^{12}$ in contrast to colloidal and granular cysts, which exhibit ring or nodular enhancement, peri-lesional oedema, and poor demarcation. ${ }^{12}$ Calcified lesion do not demonstrate oedema or contrast enhancement. ${ }^{12}$

- Cysticercosis treatment is with two cysticidal agents: albendazole and praziquantel. ${ }^{1}$ These are effective in the viable, colloid and granular stages. ${ }^{1}$
Acknowledgements The authors wish to thank Dr Rosalind Crooks (consultant radiologist) for her explanation and teaching around the submitted images.

Competing interests None.

Patient consent None.

Provenance and peer review Not commissioned; externally peer reviewed.

\section{REFERENCES}

1 Del Brutto $\mathrm{OH}$. Neurocysticerosis: a review. ScientificWorldJournal 2012;2012:159821.

2 DiGeorgio CM, Medina MT, Duron R, et al. Neurocyticercosis. Epilepsy Curr 2004:4:107-11.

Copyright 2014 BMJ Publishing Group. All rights reserved. For permission to reuse any of this content visit http://group.bmj.com/group/rights-licensing/permissions.

BMJ Case Report Fellows may re-use this article for personal use and teaching without any further permission.

Become a Fellow of BMJ Case Reports today and you can:

- Submit as many cases as you like

- Enjoy fast sympathetic peer review and rapid publication of accepted articles

- Access all the published articles

- Re-use any of the published material for personal use and teaching without further permission

For information on Institutional Fellowships contact consortiasales@bmjgroup.com

Visit casereports.bmj.com for more articles like this and to become a Fellow 